\title{
Effect of Vitamin D on the Expression Level of the IL-10 and IL-4 in Asthmatic Mice
}

\author{
Yashar Rouhi ${ }^{1}$, Farnoosh Naseri ${ }^{2}$, Elahe Tahmasebi ${ }^{3}$ (D) , Hamid Tebyanian ${ }^{3}$ (D), Mehrdad Moosazadeh \\ Moghaddam 1, * iD \\ 1 Applied Biotechnology Research Center, Baqiyatallah University of Medical Sciences, Tehran, Iran \\ 2 Laboratory Senior Technical Associate Medical Genetic Ward, Imam Hospital Complex, Tehran University of Medical \\ Sciences, Tehran, Iran \\ 3 Research Center for Prevention of Oral and Dental Diseases, Baqiyatallah University of Medical Sciences, Tehran, Iran \\ * Correspondence: mm.genetics@gmail.com;
}

Scopus Author ID 57203680638

Received: 5.05.2020; Revised: 27.05.2020; Accepted: 29.05.2020; Published: 6.06.2020

\begin{abstract}
Asthma is a chronic disease that affects the airways in the lungs and is common in many countries. Studies have shown that vitamin D levels are associated with the onset and exacerbation of asthma symptoms. Given the role of vitamin D in regulating immune responses and the importance of the two major cytokines IL-4 (an inflammatory cytokine) and IL-10 (an anti-inflammatory cytokine) in immunological processes, in this study, the relationship between vitamin D intake and the level of expression of these ILs in asthmatic mice was investigated. In the case-control study performed in three groups of mice, 10 experimental asthma mice, 10 asthmatic vitamin D-treated mice, and 10 healthy mice as the control group were studied. For analyses, after RNA extraction and cDNA synthesis, the expression level of two $I L-4$ and $I L-10$ genes was evaluated by real-time PCR. Finally, the results were analyzed by SPSS software. The results showed that in the control group, the expression level of $I L-4$ and $I L-10$ genes was 0.01 and 0.02 , respectively. Accordingly, the expression level of the $I L-4$ gene in asthmatic mice and asthmatic mice treated with vitamin D was 0.6 and 0.2 , respectively, while the expression level of the $I L-10$ in these groups was 1.2 and 2.8, respectively, which showed significant changes ( $\mathrm{p}$-value $<0.05)$ in treated mice compared to the asthmatic mice without treatment. Based on results, in asthmatic mice treated with vitamin D, a significant increase in IL-10 expression was observed (1.2 to 2.8), while IL-4 expression was decreased from 0.6 to 0.2 . It appears that vitamin D supplementation in asthmatic patients by affecting T-cell maturation and increasing anti-inflammatory IL-10 and suppressing IL-4 may play a role in reducing the symptoms of asthma.
\end{abstract}

Keywords: Asthma; IL-4; IL-10; Vitamin D.

(C) 2020 by the authors. This article is an open-access article distributed under the terms and conditions of the Creative Commons Attribution (CC BY) license (https://creativecommons.org/licenses/by/4.0/).

\section{Introduction}

Asthma is a chronic disease characterized by variable symptoms such as airway obstruction and bronchitis. The airways become swollen, inflamed, and tender in subjects with asthma, and they react vigorously to certain inhalers [1-4]. World Health Organization (WHO) reported that the number of asthma patients is 300 million among all over the world, and it has been predicted to reach 400 million by 2025 [5]. Some believe that asthma is caused by a combination of genetic and environmental factors [6-8]. Moreover, it has been shown that alterations in epigenetics and lifestyle changes increase the incidence of asthma [9-11]. In asthma, as a heterogeneous disorder, cells like Th17, Th2, Th1, Treg, macrophages, neutrophils, dendritic, airway smooth muscle cells, and epithelial cells produce cytokines 
associated with this disease. One of the essential cytokines is interleukin-4 (IL-4) [12]. IL-4 cytokine, through its function in regulating Th2 cell proliferation and survival, inhibiting Th1 differentiation, and synthesizing $\operatorname{IgE}$, is crucial at the beginning of allergic airway and humoral responses at multiple levels [13]. In humans, it can be considered as the most important cytokine in the pathogenesis of allergic diseases and isotype changes from $\operatorname{IgG}$ to $\operatorname{IgE}$ [14].

Other important cytokines include interleukin 10 (IL-10) that produced from CD4 ${ }^{+} \mathrm{Th} 2$ cells known as a cytokine synthesis inhibitory factor. IL-10 inhibits the production of IL-5 and IL-4 by Th2 cells $[15,16]$, as well as IL-2 and $I F N-\gamma$ produced by Th1 lymphocytes [17]. Therefore, pro-inflammatory responses of both adaptive and innate immune cells are inhibited by IL-10 as a fundamental anti-inflammatory cytokine. Moreover, IL-10 represses the proliferative $\mathrm{T}$ cell responses to different antigens in peripheral blood mononuclear cells [18].

Recent evidence suggests that vitamin D status may play a role in regulating inflammatory processes contributing to the development of chronic diseases [19-21]. Recently, the non-calciotropic role of $1,25-(\mathrm{OH})_{2}-\mathrm{D}$, especially its anti-inflammatory and immunomodulatory action, has been drastically regarded. Animal studies have shown the beneficial effects of vitamin D and their compounds on various immune disorders (Mathieu C). Moreover, the recent investigations have explained some of the underlying mechanisms, proposing a potential therapeutic function of vitamin $\mathrm{D}$, its analogs, and its metabolites for immune disorders in humans [22-26].

According to the results of previous studies, the prevalence of asthma is increasing worldwide [27]. Besides, according to studies on vitamin D deficiency and its effects on allergic reactions, it is necessary to investigate how this vitamin affects immunological factors and the control of allergic reactions. It seems that vitamin D treatment has anti-inflammatory effects in asthma by increasing the IL-10 expression and ultimately leading to the reduction of the IL-4 expression as an inflammatory cytokine. Therefore, the present study aimed to investigate the effect of vitamin D on IL-4 and IL-10 expression in a mouse model of asthma.

\section{Materials and Methods}

\subsection{Mice and Grouping.}

In the present study, 30 male C57BL/6 mice with a weight of $200-250 \mathrm{~g}$ were used at about 3 months of age. The experiments were approved by the Institutional Animal Care and Use Committee at Baqiyatallah University of Medical Sciences (IR.BMSU.REC.1398.197). All mice were caged and maintained according to the National Institute of Health Guidelines for the Care and Use of Laboratory Animals (Department of Health and Human Services). Mice were randomly divided into three different groups of 10 mice in each: A- healthy mice (normal control), B- mice model with asthma (positive control), and C- mice model with asthma treated by vitamin $\mathrm{D}$. Mice in group $\mathrm{C}$ were injected intraperitoneally with $5 \mu \mathrm{g} / \mathrm{kg}$ vitamin D3, dissolved in $150 \mu \mathrm{l}$ of sesame oil, three times a week.

\subsection{Development of mice model with asthma.}

On the first day of the experiments, ovalbumin solution was injected intraperitoneally into all mice except the control group ( $1 \mathrm{mg}$ ovalbumin $+50 \mathrm{mg} 10 \% \mathrm{Al}(\mathrm{OH})_{3}+0 \mathrm{ml}$ normal saline). Furthermore, on the 8th day, the ovalbumin solution $(0.02 \mathrm{mg}$ ovalbumin $+0.5 \mathrm{mg}$ $10 \% \mathrm{Al}(\mathrm{OH})_{3}+0.5 \mathrm{ml}$ normal saline) was injected intraperitoneally. For inhalation, each 
mouse received $100 \mathrm{mg}$ of ovalbumin powder dissolved in $2.5 \mathrm{ml}$ of normal saline, which was sprayed by a nebulizer and aerosol device into a closed chamber for 18 days.

\subsection{Sampling.}

On day 29, mice were anesthetized, and blood samples were collected in EDTA tubes by cardiac puncture.

\subsection{RNA extraction.}

Total RNA was extracted using the YTA RNA Extraction kit (Yekta Tajhiz Azma, Iran) according to the manufacturer's protocol. Finally, the extracted RNA was eluted with $50 \mu \mathrm{l}$ RNAase- free water and stored at $-70^{\circ} \mathrm{C}$. The RNA quality and quantity were assayed using spectrophotometric optical density measurement (wavelength, 260, and $280 \mathrm{~nm}$ ).

\section{5. cDNA synthesis.}

For cDNA synthesis, the mixture containing $1 \mu \mathrm{l}$ random hexamer primer (SinaClon, Iran), $5 \mu 1$ extracted RNA, and $6 \mu \mathrm{DEPC}$ water incubated at $65^{\circ} \mathrm{C}$ for 5 minutes. Then, $4 \mu 1$ 5X M-MLV RTase reaction buffer (Yekta Tajhiz, Iran), $2 \mu$ dNTP mix (SinaClon), $1 \mu$ DTT $(100 \mathrm{mM}), 1 \mu \mathrm{l}$ M-MLV RTase (Yekta Tajhiz, Iran) were added to each tube, resulting in a final volume of $20 \mu \mathrm{l}$; followed by incubation at $50^{\circ} \mathrm{C}$ for $60 \mathrm{~min}$ and $95^{\circ} \mathrm{C}$ for $5 \mathrm{~min}$. The synthesized cDNA was stored at $-20^{\circ} \mathrm{C}$ until use.

\subsection{Real-time PCR.}

SYBR Green real-time polymerase chain reaction technique (RT-PCR) was employed to quantify IL-4, IL-10 mRNA expression, and GAPDH as the internal control. Amplification was performed on a Corbett Rotor-Gene 6000 (Qiagen, Hilden, Germany) using SYBR Green PCR Master Mix (Fermentas). The $25 \mu 1$ of PCR mixture included $12.5 \mu 12 \mathrm{x}$ SYBR Green Master Mix, $2 \mu \mathrm{l}$ cDNA, $1 \mu \mathrm{l}$ forward-primer, $1 \mu \mathrm{l}$ reverse-primer, and $8.5 \mu \mathrm{l}$ DEPC water. The PCR condition was $95^{\circ} \mathrm{C}$ for 15 minutes, followed by 35 cycles of $95^{\circ} \mathrm{C}$ and $57^{\circ} \mathrm{C}\left(63^{\circ} \mathrm{C}\right.$ for GAPDH) for 20 and 63 seconds, respectively. For Non-template Negative Control (NTC) samples, the $2 \mu \mathrm{l}$ of DEPC water was added instead of a $2 \mu \mathrm{l}$ cDNA template. All the samples were tested in duplicate. The information of specific primers is shown in Table 1 . The accuracy and specificity of primers activity in the real-time PCR were confirmed by examining the size of the PCR products on $2 \%$ agarose gel electrophoresis.

Table 1. Primers used for real-time PCR in this study.

\begin{tabular}{l|l|l|l} 
Genes & Sequence (5' to 3') & $\begin{array}{l}\text { Size of PCR } \\
\text { Products }(\mathbf{b p})\end{array}$ & $\begin{array}{l}\text { Annealing } \\
\text { Temperature }\left({ }^{\circ} \mathbf{C}\right)\end{array}$ \\
\hline IL-4 & $\begin{array}{l}\text { Forward:5'-TCCGACCACCACTACAGCAA-3' } \\
\text { Reverse:5'-ATCTTTCAACACGCAGGACA -3' }\end{array}$ & 416 & 57 \\
\hline IL-10 & $\begin{array}{l}\text { Forward:5'-ACACATGGTATAGATGCAGC-3' } \\
\text { Reverse:5'-TTCCAAGACCTCAGGCAAGA-3' }\end{array}$ & 102 & 57 \\
\hline GAPDH & $\begin{array}{l}\text { Forward: 5'-TCGACAGTCAGCCGCATCTTCTTT-3' } \\
\text { Reverse: 5'-ACCAAATCCGTTGACTCCGACCTT-3' }\end{array}$ & 98 & 63
\end{tabular}

\subsection{Calculations for relative quantification and data analysis.}

The levels of IL-4 and IL-10 mRNA were calculated and analyzed using the $2^{-\Delta \Delta C T}$ method. Data are expressed as mean $\pm S D$. Statistical t-test was conducted for pairwise comparison, and the P-values resulted in less than 0.05 were considered significant. 


\section{Results and Discussion}

The healthy group samples were used as reference samples to compare changes between other groups. The expression of target genes in healthy mice was measured relative to GAPDH resulted in 0.01 and 0.02 for $I L-4$ and $I L-10$ genes, respectively. IL-4 and IL-10 expression in both asthma group without vitamin D3 administration and asthma group with vitamin D3 administration were significantly increased in comparison to the healthy control group ( $p<0.05$ ) (Fig. $1 \& 2$ ). Furthermore, the relative expression of IL-4 in the group with asthma that treated with vitamin D3 was significantly decreased (0.6 to 0.2$)$ in comparison to the group with asthma without vitamin D3 treatment $(p<0.05)$ (Fig. 1) while IL-10 expression was significantly increased (1.2 to 2.8 ) the group with asthma treated with vitamin D3 than those in the asthma group ( $p<0.05$ ) (Fig. 2). In addition, the real-time PCR products of GAPDH, IL-4, and IL-10 showed a single band and expected size (Fig. 3).

In recent decades, asthma has become one of the most common non-communicable diseases in the world. It is increasing due to the volume of air pollutants [28]. The pathogenesis of asthma includes the role of chemical mediators, mast cells, basophils, and platelets. Mast cells and basophils are stimulated due to the secretion of IgE from plasma cells, leading to the secretion of mediators such as IFN $\alpha$, IL-1, IL-2, IL-3, and IL-4 [29].

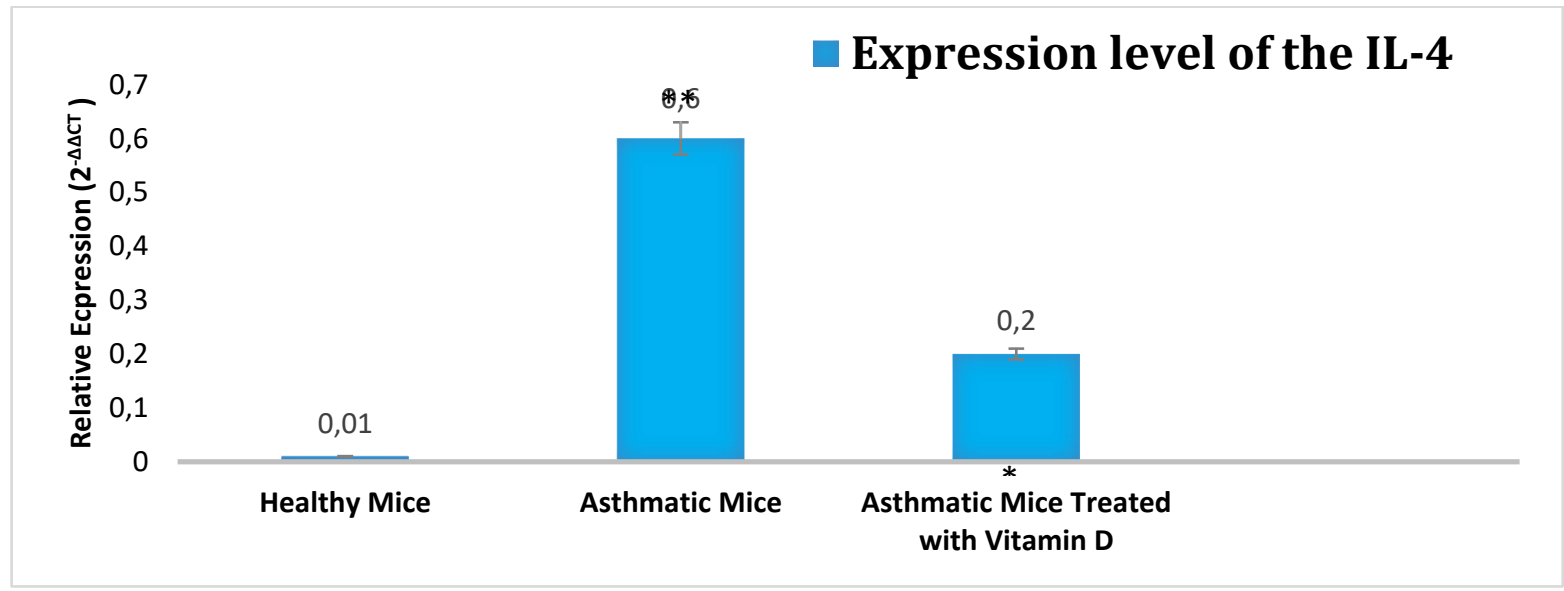

Figure 1. Comparison of the relative expression of the $I L-4$ gene between three different studied groups. ${ }^{*} p<0.05:$ Compared with the healthy group; ${ }^{*} p<0.05$ : Compared with the asthma group.

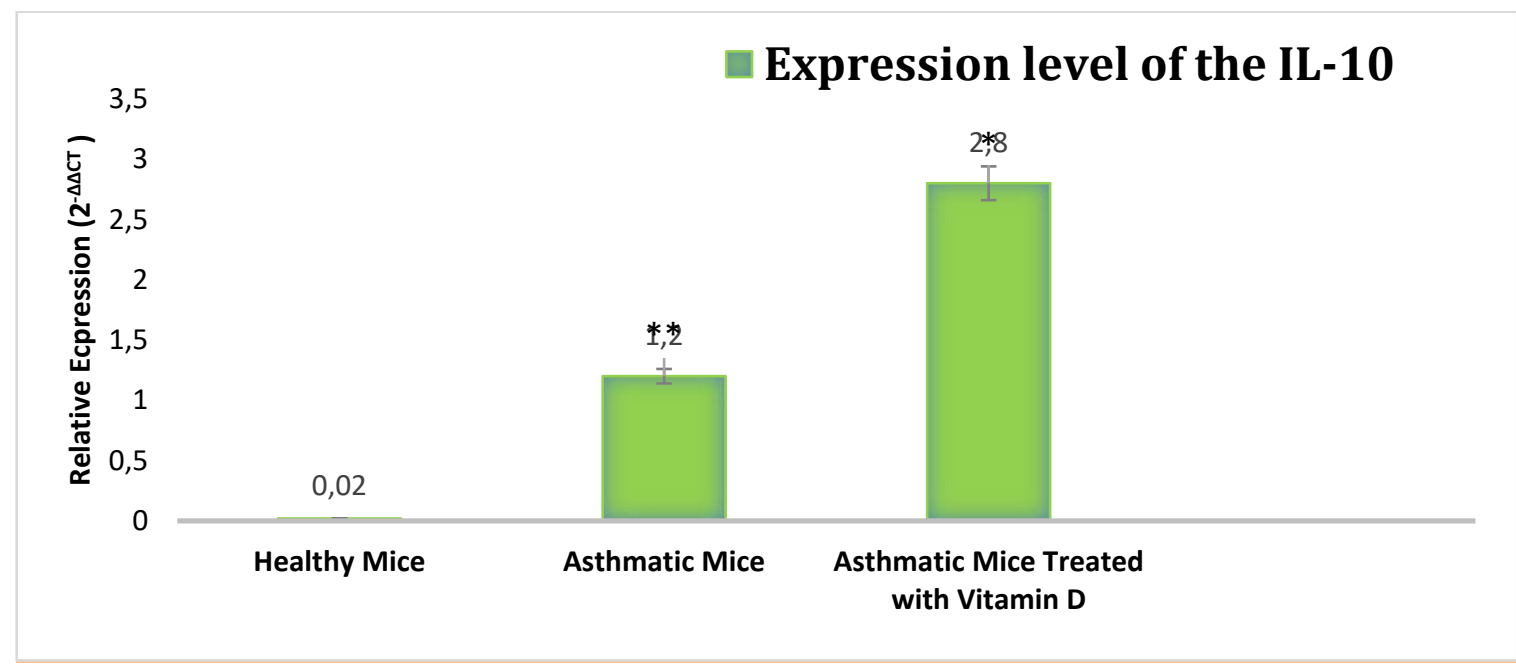

Figure 2. Comparison of the relative expression of the $I L-10$ gene between three different studied groups. ${ }^{*} p<0.05$ : Compared with the healthy group; ${ }^{*} p<0.05$ : Compared with the asthma group. 


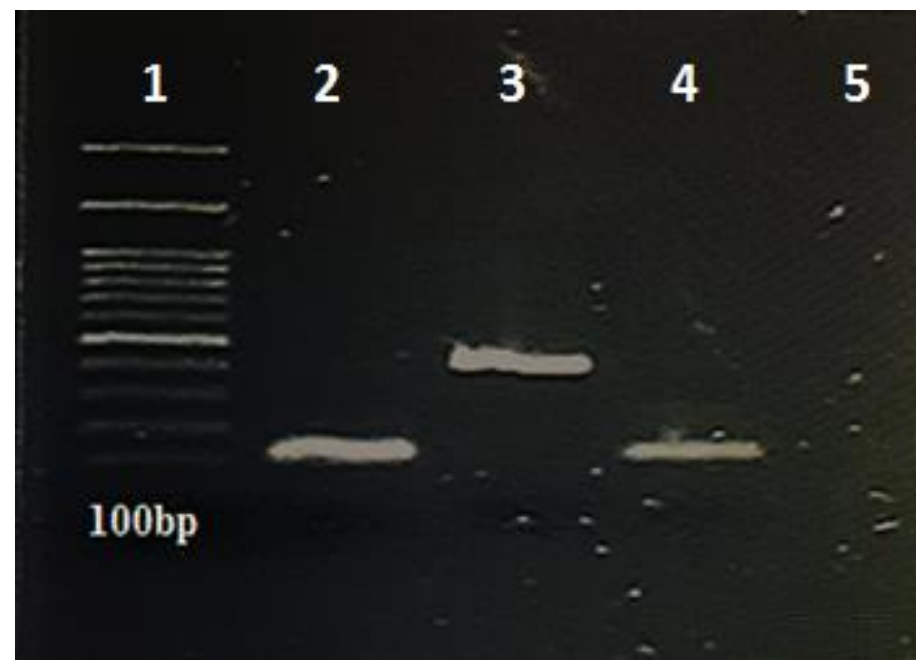

Figure 3. Real-time PCR products on $2 \%$ agarose gel. 1: 100 bp Ladder, 2: Internal Control GAPDH, $\underline{3}$ : IL-4, 4: IL-10, $\underline{\text { : NTC. }}$

However, several asthma-related concerns remain poorly recognized. Consequently, investigation of asthma pathogenesis is crucial to find innovative preventive and therapeutic targets for asthma. In the present study, we studied the expression level of IL-4 as one of the crucial and key cytokines in the development of asthma together with the IL-10 as a regulator of the immune system by dividing the experimental samples into three groups of mice. According to the results of this study, the expression of IL-4 was significantly increased in mice model of asthma compared to healthy mice, which was following the results of the investigation conducted by Tachdjian et al. in 2019. They indicated an increased level of IL-4 in mice model with asthma, which may have exacerbated asthma symptoms and remodeled airways [30]. Furthermore, Steinke reported that the expression level of IL-4 elevated in most patients with asthma [29]. Moreover, in this study, a considerable increase of IL-10 expression was observed among mice model of asthma compared to healthy mice.

Various studies have published that vitamin D plays a crucial role in many aspects of allergic and autoimmune disorders and acts as an influential factor in regulating the immune system [31, 32]. Hatami et al. studied the relationship between vitamin D levels and asthma among children. They reported that most children with asthma had vitamin D deficiency. Only $5 \%$ of the subjects had adequate levels of vitamin D. Their results also show that vitamin D deficiency was associated with the severity of asthma [33]. In 2013, Rachel et al. examined the role of vitamin D in asthma. They demonstrated that vitamin D could reduce or control asthma symptoms, and vitamin D treatment reduced IL-4 concentrations and the inflammatory responses [5]. Whereas, the influence of vitamin D on IL-10 synthesis is controversial among scholars. Several previous reports state a decrease, while others declare elevated production $[34,35]$.

In this research, the impact of vitamin D on IL-4 and IL-10 expression was studied, and the results showed the relative expression of IL- 4 was significantly decreased in the asthma group treated with vitamin D in comparison with the asthma group without any treatment. Also, the relative expression of IL-10 was substantially higher in the vitamin D treated group than the mice model with asthma. Based on the results of several studies, it can be expected that vitamin $\mathrm{D}$ treatment can help balance the levels of $\mathrm{Th}_{2}$ and $\mathrm{T}$ regulatory lymphocytes. As a result, high levels of IL-10 secreted by Treg lead to decreased levels of IL-4. Regarding the alarming prevalence of vitamin D deficiency and its effects on the incidence of allergic complications and asthma, it is necessary to examine the relationship between these two 
factors. Since asthma is a kind of Th2-type immune responses, it can be expected that this vitamin has a remarkable impact on atopic allergic responses through the induction of regulatory T-cells and the secretion of inflammatory cytokines [36]. As a result, vitamin D treatment can reduce responses and improve symptoms. However, evidence of the antiinflammatory effect of vitamin D is rare in human clinical studies. Accordingly, it is suggested that further studies must be conducted to investigate the effect of vitamin $\mathrm{D}$ in reducing the complications of asthma in human samples.

\section{Conclusions}

According to studies, increasing the level of vitamin D in mice by affecting the function of interleukins can be reduced the symptoms of the asthmatic disease. Since mice are mammalian models similar to humans, it can be concluded that Vitamin D can be also effective in strengthening the immune system in the human body. However, more studies are needed.

\section{Funding}

This research received no external funding.

\section{Acknowledgments}

The authors thank the Research Council of Baqiyatallah University of Medical Sciences for their kind help.

\section{Conflicts of Interest}

The authors declare no conflict of interest

\section{References}

1. Szefler, S.J. Advances in pediatric asthma in 2012: moving toward asthma prevention. J Allergy Clin Immunol 2013, 131, 36-46, https://doi.org/10.1016/j.jaci.2012.11.009.

2. Patel, B.; Wi, C.I.; Hasassri, M.E.; Divekar, R.; Absah, I.; Almallouhi, E.; Ryu, E.; King, K.; Juhn, Y.J. Heterogeneity of asthma and the risk of celiac disease in children. Allergy Asthma Proc 2018, 39, 51-58, https://doi.org/10.2500/aap.2018.39.4100.

3. Song, D.J.; Choi, S.H.; Song, W.J.; Park, K.H.; Jee, Y.K.; Cho, S.H.; Lim, D.H. The Effects of Short-Term and Very Short-Term Particulate Matter Exposure on Asthma-Related Hospital Visits: National Health Insurance Data. Yonsei Med J 2019, 60, 952-959, https://doi.org/10.3349/ymj.2019.60.10.952.

4. Zervas, E.; Samitas, K.; Papaioannou, A.I.; Bakakos, P.; Loukides, S.; Gaga, M. An algorithmic approach for the treatment of severe uncontrolled asthma. ERJ Open Res 2018, 4, 00125-2017, https://doi.org/10.1183/23120541.00125-2017.

5. Ober, C.; Yao, T.C. The genetics of asthma and allergic disease: a 21st century perspective. Immunol Rev 2011, 242, 10-30, https://doi.org/10.1111/j.1600-065X.2011.01029.x.

6. Apter, A.J. Advances in adult asthma diagnosis and treatment in 2012: potential therapeutics and geneenvironment interactions. $J$ Allergy Clin Immunol 2013, 131, 47-54, https://doi.org/10.1016/j.jaci.2012.11.020.

7. Menzies-Gow, A.; Canonica, G.W.; Winders, T.A.; de Sousa, J.C.; Upham, J.W.; Fink-Wagner, A.H. A charter to improve patient care in severe asthma. Adv Ther 2018, 35, 1485-1496, https://doi.org/10.1007/s12325-018-0777-y.

8. Murrison, L.B.; Brandt, E.B.; Myers, J.B.; Hershey, G.K.K. Environmental exposures and mechanisms in allergy and asthma development. J Clin Invest 2019, 129, 1504-1515, https://doi.org/10.1172/JCI124612.

9. Wills-Karp, M.; Luyimbazi, J.; Xu, X.; Schofield, B.; Neben, T.Y.; Karp, C.L.; Donaldson, D.D. Interleukin13: central mediator of allergic asthma. Science 1998, 282, 2258-61, https://doi.org/10.1126/science.282.5397.2258.

10. Chung, L.P.; Upham, J.W.; Bardin, P.G.; Hew, M. Rational oral corticosteroid use in adult severe asthma: A narrative review. Respirology 2020, 25, 161-172, https://doi.org/10.1111/resp.13730. 
11. Lee, J.; Tay, T.R.; Radhakrishna, N.; Hore-Lacy, F.; Mackay, A.; Hoy, R.; Dabscheck, E.; O'Hehir, R.; Hew, M. Nonadherence in the era of severe asthma biologics and thermoplasty. Eur Respir J 2018, 51, https://doi.org/10.1183/13993003.01836-2017.

12. Hopfenspirger, M.; Parr, S.; Townley, R.; Agrawal, D. 828 Phase I/II study of recombinant interleukin-4 receptor (IL-4R) in adult patients with moderate asthma. J. Allergy Clin. Immunol 2000, 105, S282, https://doi.org/10.1016/S0091-6749(00)91256-9.

13. Tepper, R.I.; Levinson, D.A.; Stanger, B.Z.; Campos-Torres, J.; Abbas, A.K.; Leder, P. IL-4 induces allergiclike inflammatory disease and alters $\mathrm{T}$ cell development in transgenic mice. Cell 1990, 62, 457-67, https://doi.org/10.1016/0092-8674(90)90011-3.

14. Olszak, T.; An, D.; Zeissig, S.; Vera, M.P.; Richter, J.; Franke, A.; Glickman, J.N.; Siebert, R.; Baron, R.M.; Kasper, D.L. Microbial exposure during early life has persistent effects on natural killer T cell function. Science 2012, 336, 489-493, https://doi.org/10.1126/science.1219328.

15. Moore, K.W.; de Waal Malefyt, R.; Coffman, R.L.; O'Garra, A. Interleukin-10 and the interleukin-10 receptor. Annu Rev Immunol 2001, 19, 683-765, https://doi.org/10.1146/annurev.immunol.19.1.683.

16. Schandené, L.; Alonso-Vega, C.; Willems, F.; Gerard, C.; Delvaux, A.; Velu, T.; Devos, R.; De Boer, M.; Goldman, M. B7/CD28-dependent IL-5 production by human resting T cells is inhibited by IL-10. J. Immunol. Res 1994, 152, 4368-4374, https://doi.org/10.4049/jimmunol.1901095.

17. Fiorentino, D.F.; Bond, M.W.; Mosmann, T. Two types of mouse T helper cell. IV. Th2 clones secrete a factor that inhibits cytokine production by Th1 clones. J Exp Med 1989, 170, 2081-2095, https://doi.org/10.1084/jem.170.6.2081.

18. Akdis, C.A.; Joss, A.; Akdis, M.; Faith, A.; Blaser, K. A molecular basis for T cell suppression by IL-10: CD28-associated IL-10 receptor inhibits CD28 tyrosine phosphorylation and phosphatidylinositol 3-kinase binding. FASEB J 2000, 14, 1666-8, https://doi.org/10.1096/fj.99-0874fje.

19. Van Tong, N.X.H.H.; Le Huu Song Christian, G.M.; Velavan, T.P. Vitamin D deficiency and hepatitis viruses-associated liver diseases: a literature review. World J Gastroenterol 2018, 24, 445-460.

20. Wallbaum, P.; Rohde, S.; Ehlers, L.; Lange, F.; Hohn, A.; Bergner, C.; Schwarzenböck, S.M.; Krause, B.J.; Jaster, R. Antifibrogenic effects of vitamin D derivatives on mouse pancreatic stellate cells. World $J$ Gastroenterol 2018, 24, 170-178.

21. Kiely, M.; Cashman, K.D. Summary outcomes of the ODIN project on food fortification for vitamin D deficiency prevention. Int J Environ Res Public Health 2018, 15, 2342, https://doi.org/10.3390/ijerph15112342.

22. Maalouf, N.M. The non-calciotropic actions of vitamin D: recent clinical developments. Curr Opin Nephrol Hy 2008, 17, 408, https://doi.org/10.1097/MNH.0b013e3283040c99.

23. Stanislav, A.A.; Vassu-Dimov, T. Preliminary results of the investigations regarding the association of transforming growth factor-beta1 (TGFB1) gene polymorphism to metabolic syndrome in a Romanian patients group. Biointerface Res Appl Chem 2019, 9, 3974-3978, https://doi.org/10.33263/briac93.974978.

24. Jagannath, V.A.; Filippini, G.; Di Pietrantonj, C.; Asokan, G.V.; Robak, E.W.; Whamond, L.; Robinson, S.A. Vitamin D for the management of multiple sclerosis. Cochrane Database Syst Rev 2018, 9, https://doi.org/10.1002/14651858.CD008422.pub3.

25. O'Callaghan, K.M.; Kiely, M. Systematic Review of Vitamin D and Hypertensive Disorders of Pregnancy. Nutrients 2018, 10, 294, https://doi.org/10.3390/nu10030294.

26. Skrypnyk, M.; Petrushanko, T.; Neporada, K.; Bubnov, R.; Shcherbakov, O.; Spivak, M. Effectiveness of nanocrystalline cerium dioxide for secondary prevention of inflammatory periodontal diseases in young individuals with obesity. Lett. Appl. NanoBioScience 2019, $8, \quad 754 \quad-761$ https://doi.org/10.33263/LIANBS84.754761.

27. Idani, E.; Raji, H.; Madadizadeh, F.; Cheraghian, B.; Haddadzadeh Shoshtari, M.; Dastoorpoor, M. Prevalence of asthma and other allergic conditions in adults in Khuzestan, southwest Iran, 2018. BMC Public Health 2019, 19, 303, https://doi.org/10.1186/s12889-019-6491-0.

28. Masoli, M.; Fabian, D.; Holt, S.; Beasley, R. The global burden of asthma: executive summary of the GINA Dissemination Committee report. Allergy 2004, 59, 469-78, https://doi.org/10.1111/j.13989995.2004.00526.x.

29. Steinke, J.W.; Payne, S.C.; Borish, L. Interleukin-4 in the Generation of the AERD Phenotype: Implications for Molecular Mechanisms Driving Therapeutic Benefit of Aspirin Desensitization. J Allergy (Cairo) 2012, 2012, 182090, https://doi.org/10.1155/2012/182090.

30. Tachdjian, R.; Al Khatib, S.; Schwinglshackl, A.; Kim, H.S.; Chen, A.; Blasioli, J.; Mathias, C.; Kim, H.Y.; Umetsu, D.T.; Oettgen, H.C. In vivo regulation of the allergic response by the IL-4 receptor $\alpha$ chain immunoreceptor tyrosine-based inhibitory motif. J. Allergy Clin. Immunol 2010, 125, 1128-1136. e8, https://doi.org/10.1016/j.jaci.2010.01.054.

31. Aranow, C. Vitamin D and the immune system. $J$ Investig Med 2011, 59, 881-6, https://doi.org/10.2310/JIM.0b013e31821b8755.

32. Hyppönen, E.; Berry, D.; Wjst, M.; Power, C. Serum 25-hydroxyvitamin D and IgE-a significant but nonlinear relationship. Allergy 2009, 64, 613-620, https://doi.org/10.1111/j.1398-9995.2008.01865.x. 
33. Hatami, G.; Ghasemi, K.; Motamed, N.; Firoozbakht, S.; Movahed, A.; Farrokhi, S. Relationship between Vitamin D and Childhood Asthma: a case-control study. Iran. J. Pediatr 2014, 24, 710,

34. Penna, G.; Roncari, A.; Amuchastegui, S.; Daniel, K.C.; Berti, E.; Colonna, M.; Adorini, L. Expression of the inhibitory receptor ILT3 on dendritic cells is dispensable for induction of CD4+ Foxp3+ regulatory T cells by 1, 25-dihydroxyvitamin D3. Blood 2005, 106, 3490-3497, https://doi.org/10.1182/blood-2005-052044.

35. Penna, G.; Amuchastegui, S.; Giarratana, N.; Daniel, K.C.; Vulcano, M.; Sozzani, S.; Adorini, L. 1, 25Dihydroxyvitamin D3 selectively modulates tolerogenic properties in myeloid but not plasmacytoid dendritic cells. J. Immunol. Res 2007, 178, 145-153, https://doi.org/10.4049/jimmunol.178.1.145.

36. Gombart, A.F. The vitamin D-antimicrobial peptide pathway and its role in protection against infection. Future Microbiol 2009, 4, 1151-1165, https://doi.org/10.2217/fmb.09.87. 